\title{
Cacopsylla melanoneura Has No Relevance as Vector of Apple Proliferation in Germany
}

\author{
Christoph J. Mayer, Barbara Jarausch, Wolfgang Jarausch, Wilhelm Jelkmann, Andreas Vilcinskas, and Jürgen Gross
}

First, fourth, and sixth authors: Julius Kuehn Institute-Federal Research Centre for Cultivated Plants, Institute for Plant Protection in Fruit Crops and Viticulture, Dossenheim, Germany; first, fifth, and sixth authors: Institute for Phytopathology and Applied Zoology (IPAZ), Justus-Liebig University, Gießen, Germany; and second and third authors: RLP AgroScience GmbH AlPlanta, Institute for Plant Research, Neustadt, Germany.

Accepted for publication 24 January 2009.

\begin{abstract}
Mayer, C. J., Jarausch, B., Jarausch, W., Jeklmann, W., Vilcinskas, A., and Gross, J. 2009. Cacopsylla melanoneura has no relevance as vector of apple proliferation in Germany. Phytopathology 99:729-738.

Long-term field surveys on the distribution and natural infection rates of Cacopsylla melanoneura were carried out in commercial and abandoned apple-proliferation-infected orchards throughout Germany, northern Switzerland, and eastern France. Although the infection rates of some orchards reached up to $80 \%$, only $0.09 \%$ of all C. melanoneura collected on apple were infected by the pathogen 'Candidatus Phytoplasma mali'. Despite higher population densities, no infected individual

real-time polymerase chain reaction demonstrated that the very few infected individuals of $C$. melanoneura harbored phytoplasma concentrations 10,000 times lower than individuals of C. picta, the main vector species in Germany. Oviposition bioassays showed that hawthorn is the preferred reproduction host plant for $C$. melanoneura in Germany, not apple. Because hawthorn is not a suitable host plant for ' $\mathrm{Ca}$. P. mali', it does not play a role in the spread of apple proliferation. In contrast to data reported from northwestern Italy, C. melanoneura developed on either apple or hawthorn has no relevance as a vector of apple proliferation in Germany. The existence of epidemiologically different populations is proposed.
\end{abstract} was found on wild hawthorn. Individuals of $C$. melanoneura were not able to transmit phytoplasmas to healthy plants, and even the acquisition of ' $\mathrm{Ca}$. P. mali' from infected plants was very inefficient. Quantitative
Additional keywords: 'Candidatus Phytoplasma mali'.
Phytoplasmas are bacteria lacking a cell wall that can live in two different hosts, plants and vector insects. They are responsible for several hundred plant diseases worldwide that have large economic impact (29). The phytoplasma species belonging to the apple proliferation (AP) group (AP, pear decline, and European stone fruit yellows) are the economically most important fruit tree phytoplasmas and are widespread in the temperate regions of Europe (48). 'Candidatus Phytoplasma mali' is associated with AP disease (49) which causes major economic yield losses by inducing 'witches brooms' and tasteless undersized fruit in apple (Malus domestica Borkh.) (24).

Different psyllid species belonging to the taxon Cacopsylla Ossiannilsson 1970 (Hemiptera: Psyllidae) are responsible for the transmission of European fruit tree phytoplasmas. Cacopsylla pyricola (Förster) and C. pyri (L.) have been reported to transmit pear decline, whereas $C$. pruni (Scopoli) is the vector of the European stone fruit yellows (9-12,14,26,31). Psyllid species are also considered the main vectors for AP even though the leafhopper Fieberiella florii (Stål) has also been reported as a vector $(27,53)$. In recent years, it was published that the univoltine psyllid species $C$. picta (Förster) (synonym $C$. costalis) is the vector for ' $C a$. P. mali' in northeastern Italy (19) and Germany (22). Additionally, the hawthorn psyllid C. melanoneura (Förster) was identified as another vector of this disease in northwestern Italy $(52,54,55)$. Although the vector ability of $C$. picta is indisputable because successful transmission trials have been con-

Corresponding author: J. Gross; E-mail address: Juergen.Gross@jki.bund.de

doi:10.1094/PHYTO-99-6-0729

(c) 2009 The American Phytopathological Society ducted for populations from different regions $(7,19,21,22)$, the role of the hawthorn psyllid $C$. melanoneura for the spread of AP in other apple-growing regions in Central Europe remains inconsistent. Cases of transmission of ' $\mathrm{Ca}$. P. mali' by $\mathrm{C}$. melanoneura were reported from the Aosta Valley $(52,54)$ and from Trentino, Northern Italy, although yielding a transmission rate of only $0.36 \%$ in Trentino (37). Due to the high economic impact of AP in the important apple-growing regions of Northern Italy and due to the quarantine status of ' $\mathrm{Ca}$. P. mali', a compulsory clearing of infected apple trees recently has been regulated by law in several Italian regions (17).

C. melanoneura is an oligophagous species which was recorded from apple and pear trees $(13,43)$, although its main host is hawthorn (Crataegus spp.) $(24,25,43)$. However, thus far, no precise data were published describing the risk which could arise from potentially infected hawthorn plants as well as from C. melanoneura populations on such infected plants with regard to the spread of ' $\mathrm{Ca}$. P. mali' to apple orchards. Several authors described briefly the population dynamics of $C$. melanoneura on apple $(37,47,48,54)$. Mayer and Gross (38) first analyzed the whole univoltine life cycle of this species after a thorough monitoring of two reproductive seasons. They described two obligatory migratory phases and the host plants mandatory during the life cycle of $C$. melanoneura. Here, according to Mayer and Gross (38), we introduced some new definitions in order to improve the clarity of the wording used by different authors. After their development from egg to adult on their reproduction host plants (plants on which the juvenile development occurs: apple and hawthorn), the newly hatched adults leave (first migratory phase) by switching primarily to transitional hosts plants (plants only used during migration from their reproduction host to their overwintering host or vice versa: lowland conifers) before reaching their overwinter- 
ing hosts (main host plant for feeding, but also used for overwintering: mountainous conifers). After overwintering, returning mature adults (second migratory phase) initially fly to lowland conifers (transitional host) before finally shifting to their reproduction hosts for oviposition. In this article, we will use the terms "reproduction hosts" and "overwintering hosts" for the two groups of host plant mandatory during the life cycle of $C$. melanoneura. Further, we introduce the terms "emigrant" for a young adult of C. melanoneura between hatching and maturation (this includes the first migratory phase, the emigration to overwintering host plants) and "remigrant" for a mature adult, including copulation, the second migratory phase (remigration to hawthorn or apple), and oviposition, until its death.

In the present study, we evaluated the risk of $C$. melanoneura for apple-growing areas in Germany and neighboring countries. C. melanoneura spends most of the year on conifers, whereas reproduction and juvenile development takes place in early spring $(28,43)$ on either hawthorn (Crataegus spp. L.) or apple (M. domestica). Thus, our study focused on two main objectives: (i) the investigation of hawthorn (Crataegus monogyna Jacq.) as reservoir for ' $C a$. P. mali' and (ii) the evaluation of the German population of Cacopsylla melanoneura on transmission ability for ' $\mathrm{Ca}$. P. mali'.

Vector insects often transmit phytoplasmas in a persistent manner $(8,44)$. Thus far, all evidence of phytoplasma dissemination within insects has been provided for leafhoppers only (30,32, 42,51). Following acquisition from the infected source plant, there is a latent period before the vector is able to transmit. During this time, the phytoplasmas multiply in midgut, haemocytes, and salivary glands of the insect $(30,56)$. Transmission mechanisms of phytoplasmas by leafhoppers and psyllids are similar (36); therefore, we suspect that the multiplication mechanisms in these vectors are similar as well. To prove the real vector capacity of an insect species, transmission trials under controlled conditions are essential. Determination of the phytoplasma concentration in infected insects might be a supplementary tool to assess the vector ability of a species. Today, quantification of phytoplasma can be achieved by real-time polymerase chain reaction (PCR). Specific quantitative PCR assays for ' $\mathrm{Ca}$. P. mali' $(2,24)$ were used in the present study for measuring the phytoplasma titers in the two known insect vectors of ' $\mathrm{Ca}$. P. mali', $\mathrm{C}$. melanoneura and C. picta.

Recent studies demonstrate that $C$. picta, the main vector of ' $\mathrm{Ca}$. P. mali' in Germany, uses olfactory cues (e.g., $\beta$-caryophyllene) emitted from plants for host recognition $(39,40)$. Thus, we tested the role of chemical compounds emitted by the two reproduction host plants (apple and hawthorn) of $C$. melanoneura using oviposition bioassays.

\section{MATERIALS AND METHODS}

Collection of insect and plant material. From 2002 to 2007, regular insect collections were undertaken from February to September at least every 2 weeks. Insects were collected in cultivated and uncultivated apple orchards ( $M$. domestica) in different apple-growing regions of Germany, eastern France (Alsace), and northern Switzerland. The number of collection sites per region and year are specified in Table 1 . In total, 51 different sites were investigated, which corresponds to 32 commercial apple orchards managed according to the principles of integrated pest management (IPM), six commercial apple orchards managed according to the principles of organic production, and 13 untreated abandoned or scattered orchards. The infections by ' $\mathrm{Ca}$. P. mali' were monitored by recording typical symptoms of AP disease such as witches' brooms and enlarged stipules. The infection rates by ' $\mathrm{Ca}$. P. mali' of sampling sites have been monitored in the years 2003 and 2005. These data were used to group the orchards into different infection classes.

Insects used in transmission trials were collected predominantly in one commercially managed (IPM) and two untreated orchards. The infection rate of AP in the commercial orchard was monitored regularly. Between 2002 and 2006, it increased from 41 to $57 \%$. In the abandoned orchards, the unpruned trees hardly showed typical symptoms of infections by ' $\mathrm{Ca}$. P. mali'. However, PCR testing of random samples indicated that infection rates were between 40 and $80 \%$.

Between 2002 and 2008, irregular collections of C. melanoneura were carried out on hawthorn (Crataegus monogyna) plants at specific locations next to infected apple orchards in southwest Germany (Table 2). The infection rates in the apple orchards were $10 \%$ in Rheinhessen, 20 to $80 \%$ in Vorderpfalz (abandoned untreated orchard), and $30 \%$ in Nordbaden. All insect collections were done using the beating tray method according to Müther and Vogt (41). After sampling, the collected insects were counted, stored in vials, and frozen at $-20^{\circ} \mathrm{C}$ for later identification. Determination of the collected psyllids followed the key of Ossiannilsson (43).

Shoot and root samples of hawthorn bushes (C. monogyna) were collected at sites of psyllid collections (Table 3) in the period from September to February between 2001 and 2008. Their age ranged from young 4-year-old plants to old bushes for which no exact age could be estimated. For infection rates of neighboring apple orchards, see preceding paragraph. No data were available for Alsace.

Experimental infection of hawthorn with AP. Grafting experiments were carried out at Julius-Kühn Institute at Dossenheim, Germany, for testing the susceptibility of hawthorn to an

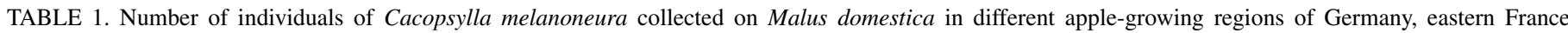
(Alsace), and Northern Switzerland (Aargau, Solothurn) between 2002 and 2007

\begin{tabular}{|c|c|c|c|c|c|c|c|c|c|c|c|c|c|}
\hline Region & $\begin{array}{c}\text { No. of } \\
\text { sites }\end{array}$ & 2002 & $\begin{array}{c}\text { No. of } \\
\text { sites }\end{array}$ & 2003 & $\begin{array}{c}\text { No. of } \\
\text { sites }\end{array}$ & 2004 & $\begin{array}{c}\text { No. of } \\
\text { sites }\end{array}$ & 2005 & $\begin{array}{c}\text { No. of } \\
\text { sites }\end{array}$ & 2006 & $\begin{array}{c}\text { No. of } \\
\text { sites }\end{array}$ & 2007 & Total \\
\hline Schleswig-Holstein & nt & $\ldots$ & 3 & 3 & 2 & 11 & 2 & 15 & $\mathrm{nt}$ & $\ldots$ & $\mathrm{nt}$ & $\ldots$ & 29 \\
\hline Rheinland & 1 & 8 & 1 & 0 & 1 & 8 & 1 & 5 & nt & $\ldots$ & nt & $\ldots$ & 21 \\
\hline Rheinhessen & 3 & 17 & 5 & 134 & 2 & 6 & 3 & 71 & nt & $\ldots$ & nt & $\ldots$ & 228 \\
\hline Vorderpfalz & 7 & 155 & 14 & 594 & 8 & 253 & 6 & 169 & 2 & 32 & 2 & 15 & 1,218 \\
\hline Südpfalz & nt & $\ldots$ & nt & $\ldots$ & $\mathrm{nt}$ & $\ldots$ & 4 & 60 & 4 & 2 & 4 & 13 & 75 \\
\hline Nordbaden & 4 & 42 & 2 & 109 & 2 & 148 & 2 & 123 & 2 & 62 & 2 & 4 & 488 \\
\hline Mittelbaden & 2 & 4 & 1 & 69 & $\mathrm{nt}$ & $\ldots$ & 2 & 832 & nt & $\ldots$ & nt & $\ldots$ & 905 \\
\hline Südbaden & nt & $\ldots$ & nt & $\ldots$ & nt & $\ldots$ & 1 & 116 & 1 & 21 & nt & $\ldots$ & 137 \\
\hline Weinsberg & nt & $\ldots$ & 1 & 2 & 1 & 1 & $\mathrm{nt}$ & $\ldots$ & nt & $\ldots$ & nt & $\ldots$ & 3 \\
\hline Bodensee & nt & $\ldots$ & 4 & 189 & 5 & 91 & 1 & 58 & 3 & 10 & nt & $\ldots$ & 348 \\
\hline Elsass & nt & $\ldots$ & $\mathrm{nt}$ & $\ldots$ & $\mathrm{nt}$ & $\ldots$ & 3 & 132 & 3 & 27 & 3 & 2 & 161 \\
\hline Aargau & nt & $\ldots$ & nt & $\ldots$ & nt & $\ldots$ & 1 & 552 & 1 & 46 & 1 & 50 & 648 \\
\hline Solothurn & nt & $\ldots$ & nt & $\ldots$ & nt & $\ldots$ & 1 & 151 & 1 & 29 & 1 & 0 & 180 \\
\hline $\mathrm{PCR}+/$ total tested & $\ldots$ & $3 / 226$ & $\ldots$ & $0 / 1,100$ & & $0 / 518$ & $\ldots$ & $1 / 2,284$ & $\ldots$ & $0 / 229$ & $\ldots$ & $0 / 84$ & $4 / 4,441$ \\
\hline
\end{tabular}

a Rate of polymerase chain reaction $(\mathrm{PCR})$-positive $(\mathrm{PCR}+)$ psyllids for 'Candidatus Phytoplasma mali' is shown on the last line; nt = not tested. 
infection with ' $\mathrm{Ca}$. P. mali'. Ten 3-year-old potted hawthorn bushes were grafted each with two root scions of AP-infected apple plants (cv. Golden Delicious) in January 2007 and maintained in an insect-free temperate greenhouse chamber (day and night temperatures $=20$ and $15^{\circ} \mathrm{C}$, respectively). In the following months, the shoots of the hawthorn plants and the apple shoots which proliferated from the scions were examined for typical symptoms of AP disease (premature reddening of leaves, enlarged stipules, and witches' brooms). Subsequently, the DNA of the phloem tissue was extracted to obtain material for PCR analysis to control whether ' $C a$. P. mali' was transmitted to hawthorn 2, 5, and 11 months after grafting.

Transmission trials. All transmission trials were carried out at AlPlanta-IPR at Neustadt/W., Germany, using psyllids captured in specific apple orchards mentioned above and on several hawthorn bushes adjacent to one of the abandoned apple orchards. Healthy and ' $\mathrm{Ca}$. P. mali'-infected micropropagated apple plants were used for the bioassays as described by Jarausch et al. $(23,24)$. After inoculation by psyllids, all test plants were treated with insecticides (Confidor at $0.16 \mathrm{~g} /$ liter or Calypso at $0.2 \mathrm{ml} / \mathrm{liter}$ ) and maintained in the greenhouse under insect-proof conditions. The numbers of test plants and psyllids are given in Tables 4 and 5 . The test plants were regularly checked for symptom expression and analyzed by PCR for infection with ' $\mathrm{Ca}$. P. mali' 6,12 , and 18 months after the inoculation process.

Transmission trials with field-collected Cacopsylla melanoneura. Natural infectivity was determined in remigrants (overwintered individuals) collected from both hawthorn plants and infected apple trees at the beginning of the remigration period between end of February and middle of March. Additionally, emigrants (newly hatched adults) were collected in May from infected apple trees just after adult emergence. Groups of 5 to 20 specimens were caged on micropropagated healthy apple plants in glass vessels or cages for 2 to 4 weeks as described by Jarausch et al. (21). The vessels were closed with an anti-aphid mesh and, after the inoculation period, dead psyllids were recollected from cages and frozen at $-20^{\circ} \mathrm{C}$ until DNA extraction.

Acquisition trials with reared Cacopsylla melanoneura. The acquisition and transmission capacity of remigrants and emigrants was examined under controlled conditions in the greenhouse. Field-collected remigrants of Cacopsylla melanoneura from apple and hawthorn were first exposed to infected apple plants for acquisition access periods (AAP) of 2 to 14 days. Dead specimens were promptly removed from the cages and frozen at $-20^{\circ} \mathrm{C}$ until DNA extraction. Groups of 5 to 20 surviving individuals were subsequently transferred to single healthy micropropagated apple plants in glass vessels for transmission and collected after death for DNA extraction. The acquisition and transmission behavior of C. melanoneura emigrants was examined separately using newly hatched adults obtained from greenhouse rearing on caged plants of either healthy apple or hawthorn. Groups of 5 to 20 specimens were caged in glass vessels on micropropagated apple plants infected with ' $\mathrm{Ca}$. P. mali' (23) for AAP of 2 to 14 days. After acquisition feeding, surviving individuals were collected from the infected plant and transferred to a healthy micropropagated apple test plant for transmission. After the inoculation period, dead

TABLE 2. Number of individuals of Cacopsylla melanoneura collected on hawthorn (Crataegus monogyna) at different sites in Germany and tested for phytoplasma infection by polymerase chain reaction (PCR) ${ }^{\mathrm{a}}$

\begin{tabular}{llcccccccc}
\hline & & \multicolumn{9}{c}{ Year $^{\mathrm{b}}$} \\
\cline { 3 - 8 } Region & \multicolumn{1}{c}{ Site } & 2002 & 2003 & 2004 & 2005 & 2006 & 2007 & 2008 \\
\hline Rheinhessen & Laurenziberg & $\ldots$ & $\ldots$ & $\ldots$ & $\ldots$ & $\ldots$ & 37 & $\ldots$ \\
Vorderpfalz & Neustadt/W. & 1,660 & 139 & 857 & 1,827 & 920 & 473 & $\ldots$ & 5,876 \\
Nordbaden & Dossenheim & $\ldots$ & $\ldots$ & $\ldots$ & $\ldots$ & $\ldots$ & $\ldots$ & 240 & 240 \\
PCR+/total tested & $\ldots$ & $0 / 1,660$ & $0 / 139$ & $0 / 857$ & $0 / 1,827$ & $0 / 920$ & $0 / 510$ & $0 / 240$ & $0 / 6,153$ \\
\hline
\end{tabular}

${ }^{a}$ The rate of PCR-positive (PCR+) psyllids for 'Candidatus Phytoplasma mali' is shown on the last line.

${ }^{\mathrm{b}}$ Number of individuals of $C$. melanoneura tested.

TABLE 3. Screening of phloem samples from hawthorn (Crataegus monogyna) for infections with 'Candidatus Phytoplasma mali'a

\begin{tabular}{llccccc}
\hline & & \multicolumn{2}{c}{ Phloem from } & & \multicolumn{2}{c}{ PCR $+^{\mathrm{b}}$} \\
\cline { 3 - 5 } \cline { 5 - 6 } Region & \multicolumn{1}{c}{ Site } & Root & Shoot & & fU5/rU4 & Nested PCR P1P7/fO1/rO1 \\
\hline Rheinhessen & Laurenziberg & 0 & 1 & 0 & $\mathrm{nt}$ \\
Vorderpfalz & Weisenheim & 0 & 2 & 0 & $\mathrm{nt}$ \\
& Meckenheim & 0 & 7 & 0 & $\mathrm{nt}$ \\
Nordbaden & Neustadt/W. & 0 & 17 & 0 & $\mathrm{nt}$ \\
Elsass (F) & Ladenburg & Dossenheim & 39 & 0 & $\mathrm{nt}$ & 0 \\
Total & Roppenheim & 0 & 5 & 0 & $\mathrm{nt}$ \\
\hline
\end{tabular}

${ }^{a}$ Root and shoot samples were collected around apple-proliferation-affected apple orchards in different apple-growing regions.

${ }^{\mathrm{b}}$ Polymerase chain reaction $(\mathrm{PCR})$ positive; $\mathrm{nt}=$ not tested.

TABLE 4. Summary of transmission trials (2002-2007) with adults of Cacopsylla melanoneura collected on apple (Malus domestica)

\begin{tabular}{llll}
\hline & & ${\text { PCR }+/ \text { total }^{\mathrm{a}}}$ & \\
\cline { 2 - 3 } Type of trial & C. melanoneura & Malus test plants & Transmission $(\%)$ \\
\hline Transmission (natural infection) & $3 / 409(0.7 \%)$ & $0 / 72$ & 0 \\
Overwintered remigrants & $0 / 95$ & $0 / 15$ & 0 \\
Emigrants (young adults) & $3 / 111(2.7 \%)$ & $0 / 4$ & 0 \\
Acquisition feeding + transmission & $0 / 67$ & $0 / 8$ & 0 \\
Overwintered remigrants & & & 0 \\
Emigrants (young adults) & & & \\
\hline
\end{tabular}

${ }^{a}$ Polymerase chain reaction-positive (PCR+) C. melanoneura/total number tested. The three PCR+ individuals of field-collected C. melanoneura are identical to those mentioned in Table 1 for the year 2002. 
psyllids were removed from the cages and frozen at $-20^{\circ} \mathrm{C}$ until DNA extraction.

DNA extraction. Insect material. The extraction procedure followed mainly the protocol of Doyle and Doyle (16). Single insects collected from apple or batches of five insects of the same sex collected from hawthorn were homogenized with a conical pestle (PP $1.5 \mathrm{ml}$; Eppendorf, Hamburg, Germany) in 1.5-ml centrifugation tubes containing 50 to $250 \mu$ of extraction buffer and in, some cases, a pinch of silicon carbide (Carborundum; SigmaAldrich, Munich, Germany) as grinding additive. The resulting DNA pellet was resuspended in $25 \mu \mathrm{l}$ (single insects) or $50 \mu \mathrm{l}$ (batches) of sterile water and stored at $-20^{\circ} \mathrm{C}$.

Plant material. Two different protocols were used for DNA extraction from plant tissues $(0.3 \mathrm{~g}$ of leaf midribs, phloem from shoots or phloem from roots). DNA extraction of plant material generally followed the protocol described above by Doyle and Doyle (16). The second extraction method was employed because the reaction was inhibited by hawthorn compounds. In these cases, the silica capture method protocol for total nucleic acids extraction described by Rott and Jelkmann (46) was adopted. The resulting DNA was resuspended in 100 to $150 \mu$ of sterile water and stored at $-20^{\circ} \mathrm{C}$. In both protocols $(16,46)$, the extraction buffers contained 2-mercapto ethanol as antioxidation agent. In this study, this chemical was exchanged with sodium metabisulfide $(2 \%)$.

PCR analysis. PCR amplification of phytoplasma 16S rDNA was routinely carried out using universal ribosomal primers fU5/P7 $(34,47)$ on DNA samples from psyllids. Samples showing unclear results in direct PCR were further analyzed with nested PCR. For this, a ' $C a$. P. mali'-specific assay described by Jarausch et al. (25) was used. Briefly, nonribosomal primers AP5/AP6 were employed for a first PCR and $1 \mu \mathrm{l}$ of the PCR product was subjected to a second PCR with the specific primers AP3/AP4. The cycle conditions were as described by Jarausch et al. (25). Ribosomal DNA from insects collected from hawthorn in 2008 was amplified with nested PCR using the universal primers $\mathrm{P} 1 / \mathrm{P} 7(15,47)$ and then the AP-group-specific primer pair fO1/rO1 on $1 \mu \mathrm{l}$ of the first amplicon (34). DNA extracts of plant samples were analyzed in direct PCR with universal, ribosomal primers fU5/rU4 $(1,34)$ or specific primers fAT/rAS (50) as described. DNA from some hawthorn samples (Dossenheim, Ladenburg, transmission trial after 11 months) was subjected to nested PCR using the primers $\mathrm{P} 1 / \mathrm{P} 7$ and fO1/rO1 as mentioned above. Aliquots ( 5 to $8 \mu \mathrm{l}$ ) of each PCR product were electrophoresed on a $1 \%$ agarose gel containing ethidium bromide at $0.3 \mu \mathrm{g} / \mathrm{ml}$ in $1 \times$ TAE buffer (40 mM Tris, $20 \mathrm{mM}$ acetic acid, $1 \mathrm{mM}$ EDTA, $\mathrm{pH}$ 8.0). The DNA was visualized and photographed while exposed to UV light (302 $\mathrm{nm})$.

Quantitative real-time PCR. The phytoplasma concentrations in infected individuals of $C$. melanoneura and $C$. picta were determined by quantitative real-time PCR. For this, the assay based on SYBR Green technology published by Jarausch et al. (24) was used. This assay amplifies a specific gene fragment of ' $C a$. P. mali' with the primers AP3/AP4. A 10-fold dilution series of $10^{8}$ to $10^{1}$ of a plasmid carrying the target gene fragment of 'Ca. P. mali' was carried out in PCR-negative DNA extracts of
C. melanoneura. Naturally infected individuals of C. picta were used as a positive control. The quantitative PCR assay was carried out on a Chromo4 Real-Time PCR detector (MJ Research, Waltham, MA) as described. The phytoplasma concentration determined in the sample was referred to as the phytoplasma concentration in one single individual. The differences between phytoplasma titers of the two species of Cacopsylla were compared by one-way analysis of variance (ANOVA) followed by least significant difference (LSD) post hoc tests (STATISTICA 5.5; StatSoft Inc., Tulsa, OK).

Oviposition bioassays. Test insects. Psyllids were collected from Picea abies L. (Weißer Stein, Dossenheim, Germany) on 28 February and 5 March before remigration to Crataegus spp. Even though the psyllids already showed frequent mating behavior, they were kept in a cage on potted $P$. abies plants in a tempered greenhouse chamber $\left(10^{\circ} \mathrm{C}\right.$ constant) until 9 to 17 March to increase their motivation for oviposition. Because only one $C$. affinis male $(0.65 \%)$ was detected among all collected male psyllids, any risk of contamination with $C$. affinis females should be insignificant.

Experimental setup. Oviposition preferences of gravid $C$. melanoneura females were tested in dual choice bioassays. Individual females were set in transparent plastic boxes (Mepal-Rosti, 19 by 15 by $9 \mathrm{~cm}$; Tischer Gastro, Heidelberg, Germany), each together with two twigs (length $=5 \mathrm{~cm}$ ) of either apple and hawthorn, apple and plum, or hawthorn and plum, which were drawn into water-filled glass vials sealed with Nescofilm (Bando Chemical Inc. Ltd, Japan). The boxes were covered by a lid with a ventilation hole $(\approx 9.5 \mathrm{~cm}$, closed by Saran tissue, mesh width $=$ $0.4 \mathrm{~mm}$ ). Each experimental setting started with 15 females but, due to mortality, the number of valid repeats reduced. The oviposition set-up was placed in a climate chamber at $20^{\circ} \mathrm{C}$ and a light regimen of day and night $=12 \mathrm{~h}$ each. After $72 \mathrm{~h}$, the number of eggs deposited on the twigs was counted by dissecting the material under a binocular.

\section{RESULTS}

Natural infection rates of $\boldsymbol{C}$. melanoneura. For the monitoring of the field populations of psyllids, different apple orchards with a wide range of infestation by ' $\mathrm{Ca}$. P. mali' have been selected. This spectrum included commercial orchards with integrated production or organic farming, as well as field sites of abandoned or scattered orchards without any treatment. The infection rates in orchards with integrated production varied from $<1 \%$ to $>50 \%$ (Table 6 ). The organically grown orchards showed lower infection rates of only $5 \%$. In contrast, abandoned or scattered orchards were highly AP infected. The 7-year-long survey of the psyllid populations in these different orchards demonstrated that $C$. melanoneura was present in all investigated regions in Germany, eastern France, and northern Switzerland (Table 1). Despite the regular presence of $C$. melanoneura, its population densities and dynamics showed strong variations among the different areas and years of investigation. Coincidently for all investigated areas, the highest number of individuals was collected in 2005 followed by a severe breakdown of the popu-

TABLE 5. Summary of transmission trials (2002-2007) with adults of Cacopsylla melanoneura collected on hawthorn (Crataegus monogyna)

\begin{tabular}{|c|c|c|c|}
\hline \multirow[b]{2}{*}{ Type of trial } & \multicolumn{2}{|c|}{ 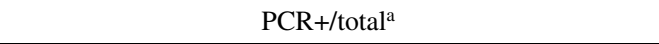 } & \multirow[b]{2}{*}{ Transmission $(\%)$} \\
\hline & C. melanoneura & Malus test plants & \\
\hline \multicolumn{4}{|c|}{ Transmission (natural infection) } \\
\hline Overwintered remigrants & $0 / 173$ & $0 / 6$ & 0 \\
\hline Emigrants (young adults) & nt & $\mathrm{nt}$ & $\mathrm{nt}$ \\
\hline \multicolumn{4}{|c|}{ Acquisition feeding + transmission } \\
\hline Overwintered remigrants & $3 / 1,359(0.2 \%)$ & $0 / 10$ & 0 \\
\hline Emigrants (young adults) & $0 / 392$ & $0 / 9$ & 0 \\
\hline
\end{tabular}

${ }^{a}$ Polymerase chain reaction-positve $(\mathrm{PCR}+)$ C. melanoneura/total number tested; $\mathrm{nt}=$ not tested. 
lation in the years 2006 and 2007. The examination by PCR of more than 3,400 individuals of $C$. melanoneura collected over a period of 6 years from different German sites, supplemented by 828 individuals from northern Switzerland and 161 individuals from eastern France collected and examined over 3 years, revealed only four natural infections by ' $\mathrm{Ca}$. P. mali' (0.09\%) (Table 1). In 2002, three infected individuals were found in the region Vorderpfalz and, in 2005, one individual captured in Alsace tested positive for ' $C a$. P. mali'. As shown in Table 6, all infected psyllids were caught in highly AP-infected orchards. The examination of nearly 6,000 individuals of $C$. melanoneura collected in the region of Neustadt on hawthorn over a period of 7 years, and supplemented by collections in Rheinhessen (2007) and Dossenheim (2008), revealed no infections (Table 2).

Transmission trials with $C$. melanoneura collected on apple. A small number of young emerged emigrants was analyzed just before starting their migration to the overwintering hosts in early summer. In all, 3 of 409 remigrants $(0.7 \%)$ (Table 4$)$ collected from apple were infected with ' $\mathrm{Ca}$. P. mali', whereas none of the field-collected emigrants bore the agent. Likewise, no test plant became infected and, thus, no transmission occurred.

In order to elucidate the potential vector capacity of remigrants and emigrants of $C$. melanoneura, induced acquisition feeding and subsequent direct transmission were studied under controlled conditions. Only 3 of 111 remigrants and 0 of 67 young emigrants acquired the phytoplasma from infected plants under forced conditions (Table 4), corresponding to an acquisition rate of $2.7 \%$ for remigrants and no acquisition for emigrants, respectively. In no case did healthy test plants became infected during the incubation period.

Transmission trials with $C$. melanoneura collected on hawthorn. The natural infection rate and the retention of infectivity was investigated in overwintered adults of $C$. melanoneura $(n=$ 173) collected from wild hawthorn bushes in the surroundings of apple orchards in early spring at the beginning of the remigration period. None of the overwintered adults was infected with the pathogen (Table 5) and, thus, no transmission appeared.

Further, the potential vector behavior was compared for individuals of $C$. melanoneura collected from apple with specimens derived from hawthorn in order to determine biological differences among these two populations. Comparable acquisition or transmission trials were carried out as described for C. melanoneura captured from apple (see above). The results of acquisition and transmission trials are summarized in Table 5. Only 3 of 1,359 remigrants as well as 0 of 392 emigrants, which were tested after both passages (acquisition and subsequent transmission feeding), acquired the agent from the inoculum plants. In no case did a transmission from an infected Malus to a healthy Crataegus test plant occur.

Determination of the concentration of ' $\mathrm{Ca}$. P. mali' in infected individuals of $\boldsymbol{C}$. melanoneura and $\boldsymbol{C}$. picta. The mean phytoplasma concentrations in infected individuals of $C$. melanoneura determined by quantitative real-time PCR are given in Figure 1 (white bars). The number of phytoplasmas in one individual of $C$. melanoneura collected from apple $(n=1)$ was $<40,000$ and could be increased in forced acquisition experiments on apple to an amount of $\approx 600,000$ (C. melanoneura collected from apple, $\mathrm{n}=3$ ) or 90,000 (C. melanoneura collected from hawthorn, $\mathrm{n}=3$ ) phytoplasmas per insect. These titers of phytoplasma concentrations in individuals of $C$. melanoneura are much lower than those determined in remigrated individuals of $C$. picta collected from apple (Fig. 1, black bar). The number of phytoplasmas (' $\mathrm{Ca}$. P. mali') in individuals of $C$. picta $(n=7)$ reached an average of 325 million, corresponding approximately to a titer 10,000 times higher compared with the natural infection rates of $C$. melanoneura. The mean number of phytoplasmas found in $C$. melanoneura (total of all treatments $=311,414$ phytoplasmas/insect) was significantly different from the number found in $C$. picta (oneway ANOVA: $\mathrm{df}=1, F=36, P<0.001$; followed by LSD post hoc test; $P<0.001$ ).

Determination of natural infection of hawthorn by ' $\mathrm{Ca}$. P. mali'. The examination of roots and shoots of 90 hawthorn bushes sampled in different regions showed neither visual symptoms nor positive results in single PCRs, regardless of which general phytoplasma primers were used (P1/P7 or fU5/rU4). Moreover, the samples from Nordbaden which were additionally analyzed by nested PCR using primers specific for fruit tree phytoplasmas (fO1/rO1) revealed no infections as well (Table 3).

Experimental inoculation of hawthorn with ' $\mathrm{Ca}$. P. mali'. In all, 9 of 10 hawthorn plants developed connections to both grafted apple scions. Eleven scions on eight test plants had sprouted 2 months after grafting. Some of the grafted apple twigs developed typical symptoms of AP disease. Nevertheless, this was not observed with hawthorn twigs. Furthermore, leaves of apple scions of six plants were colored red. Additionally, on two plants, the leaves of the scions had enlarged stipules and, on one plant, a witches' broom was formed. PCR analysis of phloem material from newly developed shoots of the apple scions with ' $\mathrm{Ca}$. P. mali'-specific primers fAT/rAS revealed infections on six plants. The observed symptoms on the shoots of the scions corresponded mainly with the results of the PCR analysis. PCR analyses of the hawthorn rootstocks were carried out with the same primers 2 and 5 months after grafting of the infected apple scions. ' $C a$. P. mali' was never detected in any of the 10 test plants. In order to ensure that negative results of the PCR analysis were not generated by a very low titer of ' $\mathrm{Ca}$. P. mali', the more sensitive nested PCR (3) was used for the analysis 11 months after grafting (primers P1/P7 followed by fO1/rO1), but no infection of hawthorn could be determined.

Natural population densities of $C$. melanoneura on apple or hawthorn. The comparison of the number of $C$. melanoneura remigrants collected from one specific hawthorn site in south-

TABLE 6. Relationship between infection status of the orchard and number of phytoplasma-infected Cacopsylla melanoneura

\begin{tabular}{|c|c|c|c|c|c|c|}
\hline Type of orchard & No. of orchards & Years of sampling & Classes of infection & No. tested ${ }^{\mathrm{a}}$ & No. PCR $+^{\mathrm{b}}$ & Infection $(\%)$ \\
\hline Organic farming & 2 & 2004-2005 & $<1$ & 20 & 0 & 0 \\
\hline Organic farming & 4 & $2002-2005$ & $1-5$ & 112 & 0 & 0 \\
\hline Integrated production & 3 & 2003-2007 & $<1$ & 44 & 0 & 0 \\
\hline Integrated production & 8 & 2002-2006 & $1-5$ & 616 & 0 & 0 \\
\hline Integrated production & 7 & $2002-2007$ & $5-10$ & 1208 & 0 & 0 \\
\hline Integrated production & 7 & 2002-2007 & $10-20$ & 1049 & 0 & 0 \\
\hline Integrated production & 4 & 2002-2007 & $20-30$ & 313 & 0 & 0 \\
\hline Integrated production & 2 & $2005-2007$ & $30-50$ & 218 & 1 & 0.5 \\
\hline Integrated production & 1 & 2002-2007 & $>50$ & 313 & 2 & 0.6 \\
\hline Abandoned (untreated) & 7 & $2002-2006$ & $25-50$ & 369 & 0 & 0 \\
\hline Abandoned (untreated) & 6 & $2002-2005$ & $>50$ & 179 & 1 & 0.6 \\
\hline Total & 51 & $\ldots$ & $\ldots$ & 4,441 & 4 & 0.09 \\
\hline
\end{tabular}

a Number of $C$. melanoneura individuals tested.

b Polymerase chain reaction-positve $(\mathrm{PCR}+)$. 
western Germany (Vorderpfalz) at the beginning of the remigration period demonstrated that the population density on hawthorn was much higher than on apple (Table 7). The data assembled in Table 7 picture the situation of the population density of overwintered $C$. melanoneura which were collected in the vicinity of Neustadt in a commercial apple orchard and an adjacent hawthorn site during the peak of population of remigrants (March). Influence of pesticide treatment could largely be excluded because sampling took place before the season's first treatments.

To permit a reliable comparison, numbers of captured individuals are presented as individuals per branch. This value takes into account the heterogeneous numbers of branches sampled on apple (100 per date) and hawthorn (25 per date) as well as the nonidentical frequencies for psyllid sampling on the two host plants. The calculated number of individuals per branch clearly shows that, during the peak of remigration (middle March), the population density on hawthorn was $\approx 50$ to 150 times higher than on apple. This result underlines that hawthorn is the main host plant for $C$. melanoneura and that, under natural conditions, it is preferentially frequented by remigrants $(28,43)$.

Oviposition bioassays. The numbers of eggs laid by gravid females of $C$. melanoneura caught on $P$. abies just before remigrating to their reproduction hosts were determined in oviposition bioassays and are presented in Figure 2. The C. melanoneura females significantly preferred leaves of hawthorn to those of apple for oviposition (Fig. 2A). Furthermore, they also preferred leaves of hawthorn and apple (confirmed reproduction host plants) to those of the nonhost plant plum (Fig. 2B and C). The number of eggs laid on apple compared with hawthorn was significantly reduced.

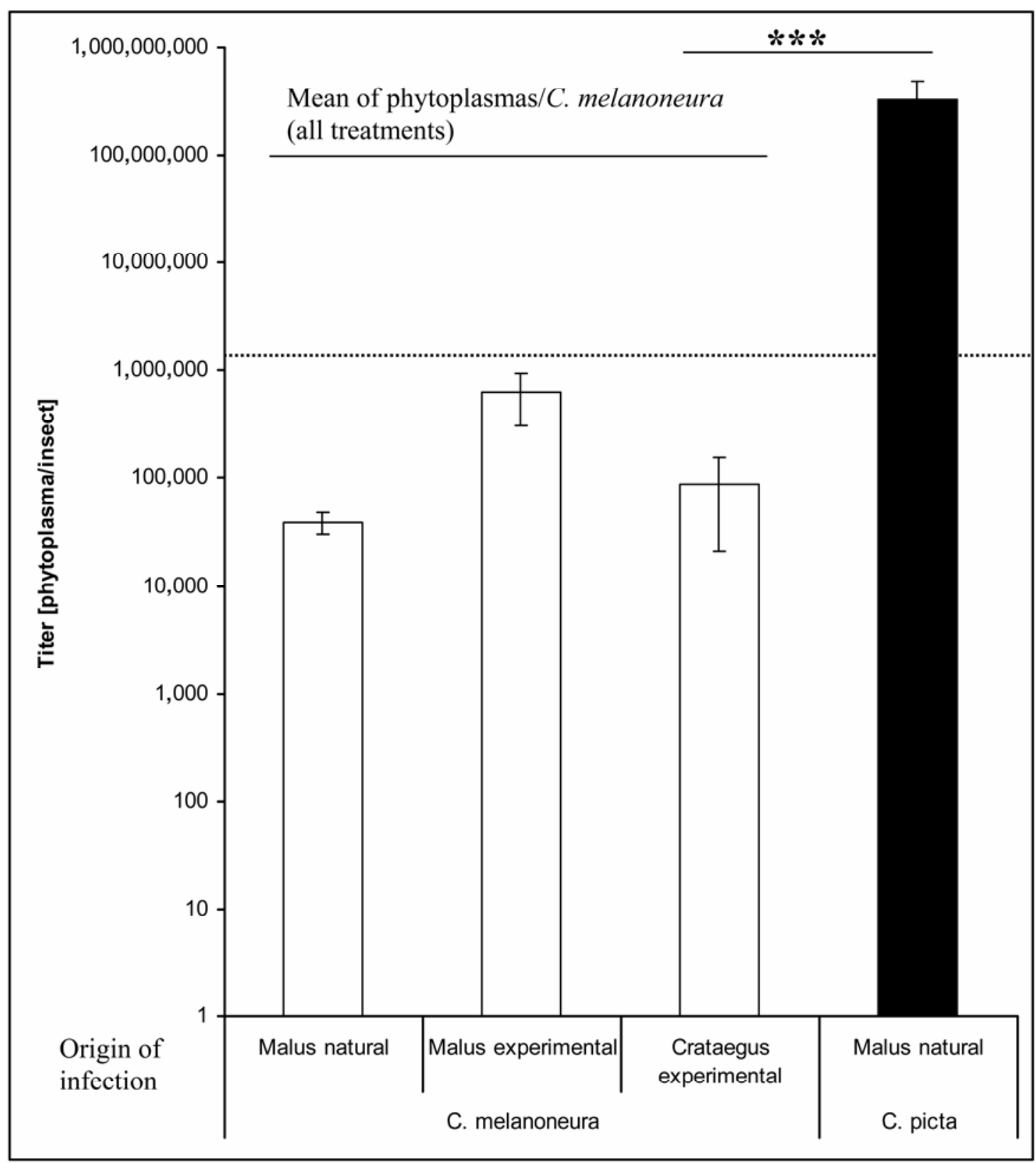

Fig. 1. Mean concentrations and standard deviations of 'Candidatus Phytoplasma mali' numbers in the body of Cacopsylla melanoneura remigrants collected from Malus or Crataegus spp. and of naturally infected C. picta remigrants from Malus spp. as determined by quantitative real-time polymerase chain reaction. $C$. melanoneura was either naturally infected or experimentally infected by feeding on infected Malus spp. The limit for successful transmission as published by Jarausch et al. (20) is indicated by a dotted line. The mean number of phytoplasmas found in C. melanoneura (total of all treatments [white bars]: 311,414 phytoplasmas/insect) differs from the number found in the hemolymph of $C$. picta (statistically significant; one-way analysis of variance: $\mathrm{df}=1, F=36, P<$ 0.001 , followed by least significant difference post hoc test, $P<0.001$ ). 


\section{DISCUSSION}

The first objective of our work was to study the possibility of whether hawthorn (Crataegus monogyna), the main reproduction host of Cacopsylla melanoneura, could serve as an additional reservoir for ' $\mathrm{Ca}$. P. mali', promoting the spread of the phytoplasma within the vector population. This would be of epidemiological relevance and could be detrimental to apple growers. Thus, we analyzed the natural infection rates of wild hawthorn plants by ' $\mathrm{Ca}$. P. mali'. No natural infection of hawthorn could be revealed and it was not possible to infect hawthorn plants experimentally; therefore, we concluded that wild Crataegus monogyna plants do not represent a suitable reservoir for ' $\mathrm{Ca}$. P. mali'.

The results of the behavioral bioassays revealed that remigrants of Cacopsylla melanoneura which returned from their overwintering hosts preferred hawthorn plants to apple trees for oviposition. This implies that they will reproduce preferentially on hawthorn and will settle on apple plants only occasionally. As a result, there is a reduced probability for transmission of ' $\mathrm{Ca}$. $\mathrm{P}$. mali' between $C$. melanoneura's two host plants, apple and hawthorn. Our investigations of $C$. melanoneura populations in southwestern Germany support these findings by showing that densities on hawthorn were more than 10 times higher than on apple in abandoned orchards (38) and 50 to 100 times higher than on apple in conventionally managed orchards. Only when females had no possibility to oviposit on hawthorn did they accept apple (Fig. 2). However, the number of deposited eggs decreased to only half the number laid on hawthorn. In conclusion, $C$. melanoneura strongly prefers hawthorn as its main host plant for reproduction. In case no hawthorn is available for oviposition or after accidental settling on apple, females are capable of learning host-specific cues and changing their preference to apple, another suitable host plant for reproduction (38). These results explain the small but existing numbers of $C$. melanoneura reproducing on apple in
Germany. Consequently, because $C$. melanoneura primarily reproduces on hawthorn (38), the major proportion of the population will never get into contact with ' $\mathrm{Ca}$. P. mali' and, therefore, will neither acquire nor transmit it.

The second objective of the present study was to investigate the vector ability of $C$. melanoneura in Germany and neighboring regions and, thus, to assess the risk for the spread of ' $\mathrm{Ca}$. P. mali' by this psyllid species. Although $C$. picta was first described as a vector of ' $C a$. P. mali' in Trentino (19), Tedeschi et al. (54) identified $C$. melanoneura as the main vector of the agent in northwestern Italy. During a 3-year survey, they determined the population dynamics of $C$. melanoneura in apple orchards by regular collections between January and July. Using the beating tray method, they always found more remigrants than emigrants, showing the highest population densities of the overwintered remigrants in mid-March $(54,55)$. Similar population dynamics were reported for Trentino (37). These data correspond to the population dynamics of $C$. melanoneura in Germany (38). In that study, a population peak of the remigrants was detected in midMarch but only low numbers of emigrants from mid-May to the beginning of July. In the present study, $\approx 4,500$ individuals were collected in more or less affected apple orchards in different German and neighboring European regions. The overwintered remigrants constituted the main portion of these collections while the number of springtime individuals (emigrants) was negligible, confirming the observations of Tedeschi et al. $(54,55)$. Among the 4,441 specimens tested by PCR with specific primers, we found only four remigrants and no emigrant naturally infected with ' $\mathrm{Ca}$. P. mali'. This represents a natural infection rate of only $0.09 \%$ in Germany compared with mean infection rates of 3.6 and $2.8 \%$ of remigrants reported from northern Italy (55). During our longterm study in Germany, naturally infected emigrants were never found, whereas Tedeschi and coworkers calculated a natural infection rate of $\approx 0.8 \%$ (55). Because the infection with the

TABLE 7. Population densities of overwintered remigrants of Cacopsylla melanoneura collected on apple (Malus spp.) and hawthorn (Crataegus spp.) at untreated sites in the surroundings of Neustadt during the peak of population in the middle of March ${ }^{\mathrm{a}}$

\begin{tabular}{|c|c|c|c|c|c|c|}
\hline \multirow[b]{2}{*}{ Year } & \multicolumn{3}{|c|}{ Malus spp. } & \multicolumn{3}{|c|}{ Crataegus spp. } \\
\hline & No. of branches & Total individuals & Individuals/branch & No. of branches & Total individuals & Individuals/branch \\
\hline 2002 & 400 & 50 & 0.13 & 75 & 1,623 & 21.64 \\
\hline 2003 & 200 & 57 & 0.29 & 50 & 774 & 15.48 \\
\hline 2005 & 100 & 20 & 0.2 & 25 & 310 & 12.40 \\
\hline 2006 & 200 & 3 & 0.02 & 75 & 170 & 2.27 \\
\hline 2007 & 100 & 1 & 0.01 & 25 & 180 & 7.20 \\
\hline
\end{tabular}

a There were 100 branches per sample on apple and 25 branches per sample on hawthorn.

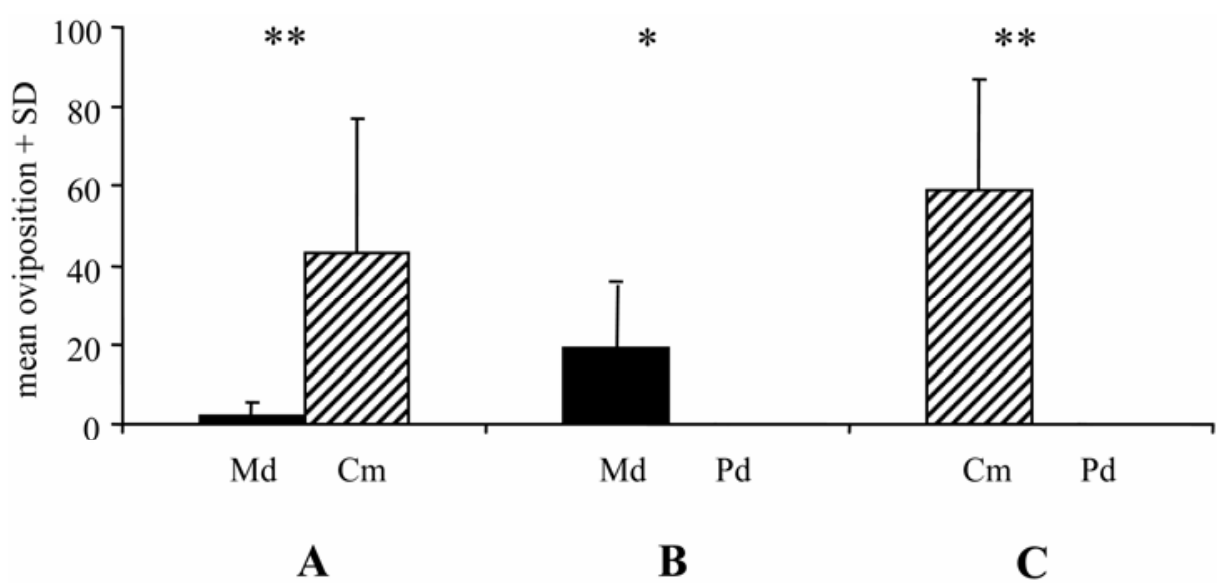

Fig. 2. Mean number and standard deviation of eggs deposited by Cacopsylla melanoneura on different plant species in dual-choice tests. The gravid females were collected from spruce just before remigrating to reproduction host plants. $\mathrm{Cm}=$ Crataegus monogyna $; \mathrm{Md}=$ Malus domestica $; \mathrm{Pd}=$ Prunus domestica . The differences are statistically significant (** and * indicate $P<0.01$ and 0.05 , respectively, Wilcoxon matched-pairs test). 
pathogen was always higher in the more abundant remigrants, they suggested that the overwintered generation plays a crucial role in vectoring ' $\mathrm{Ca}$. P. mali'.

All phytoplasma-infected $C$. melanoneura were caught in highly AP-infected orchards. Despite the high probability of phytoplasma acquisition, only four PCR-positive individuals could be identified. These field-collected data reflect the results of the acquisition-transmission experiments, which demonstrate that phytoplasma acquisition by $C$. melanoneura in Germany is very inefficient.

The magnitude of natural infection only indicates that an insect may naturally acquire a pathogen to a certain extent but does not demonstrate effective transmission behavior of a species $(57,58)$. For receiving clear evidence on the transmission ability of a species, transmission trials have to be conducted (36). Therefore, we examined the ability of $C$. melanoneura for vectoring ' $\mathrm{Ca}$. P. mali' within variable experimental designs using $\approx 100$ test plants and $\approx 500$ adults collected from apple. The experimental designs corresponded to those used to demonstrate the transmission capacity of $C$. picta (19-21). However, there was no successful transmission of ' $\mathrm{Ca}$. P. mali' to healthy test plants. This result may be due to the very low percentage $(0.7 \%)$ of naturally infected remigrants used in the transmission trials. This low portion could be raised only slightly by induced acquisition feeding to $2.7 \%$, which is lower than the natural infection of remigrants measured by Tedeschi et al. (55) in northwestern Italy. Experiments with emigrants resulted in neither any natural infection nor any induced acquisition. Unlike our results, Tedeschi et al. (52) obtained positive transmissions with naturally infected remigrants as well as with experimentally infected nymphal instars and emigrants.

Interplant spread of phytoplasma is naturally accomplished by insect vectors. In order to convert an infected vector individual to an effective vector, phytoplasmas must permeate two physical barriers within the insect: the basal lamina and surrounding cells of the gut and salivary glands. Vector morphology and physiology, as well as the phytoplasmas' molecular tool kit, may likewise influence the efficiency of a potential vector $(6,18,51,58)$. Furthermore, the ability for multiplication of phytoplasmas in their vector insects may also influence their capability as a vector. Quantitative evidence of phytoplasma multiplication in the vector insects has been provided using enzyme-linked immunosorbent assay $(5,30)$, competitive PCR (33), dot hybridization using DNA probes (42), and real-time PCR (4). According to these articles, an increase in phytoplasma titer in insects transferred to healthy plants after feeding on infected plants is direct evidence of phytoplasma multiplication in different organs of insects. Thus, we assume that a high phytoplasma titer in PCR-positive psyllids could be an assessment of its vector capacity. We used a quantitative real-time PCR assay based on SYBR green developed for the quantification of ' $\mathrm{Ca}$. P. mali' in insects and plants (24). Jarausch et al. (20) showed for C. picta, the indisputable vector of ' $C a$. P. mali' in Germany $(20,21)$, that the phytoplasma load in the insect body seems to be crucial for a successful transmission and proposed the determination of a minimum threshold of phytoplasma for an efficient transmission. To evaluate the concentration of ' $\mathrm{Ca}$. P. mali' in individuals of $C$. melanoneura, which gave positive signals in standard PCR, we applied the same approach and used several individuals of naturally infected $C$. picta as reference. The phytoplasma titer in overwintered $C$. melanoneura always ranged below $10^{6}$, even after an induced acquisition on infected apple plants (Fig. 1). The mean titer found for all examined C. melanoneura was 311,414 copies of phytoplasma DNA, displaying only one-third of the minimum threshold found for an effective transmission by $C$. picta. The populations of $C$. melanoneura in Germany and neighboring countries were capable of acquiring ' $\mathrm{C} a$. P. mali' by feeding on infected apple trees in certain circumstances but, for some reasons, the phytoplasma titer did not increase to a threshold permitting transmission. Thus, we conclude that, in Germany, C. melanoneura has to be considered to be a nonvector for the agent of the AP disease.

Thus far, no comparable quantification data are available from the effective vector population of $C$. melanoneura from the Aosta Valley in northern Italy. Pedrazzoli et al. (45) quantified the titer of ' $\mathrm{Ca}$. P. mali' in overwintered remigrants of $C$. picta, the main vector in Trentino, and of $C$. melanoneura after variable acquisition periods. Interestingly, they found that the two species did not differ in the mean phytoplasma titer during the acquisition period. However, the phytoplasma titer increased in C. picta but not in $C$. melanoneura during the latent period. They hypothesized that the low titer measured directly after acquisition feeding represents the amount of the pathogen uptake from the phloem sap. After having reached the specific organs where the main multiplication could take place, the pathogen titer would have risen. This hypothesis supports our observation that a certain minimum phytoplasma load in the insect body is necessary for an efficient transmission and that the rating of the phytoplasma titer is important to estimate whether an insect species is an efficient vector or not.

The data obtained in the present study are not in agreement with the results reported from a specific region in northwestern Italy. This raises the question about the existence of different populations of $C$. melanoneura with different capacities to acquire and transmit ' $C a$. P. mali'. Intermediary data have been obtained in another important apple-growing region in northeastern Italy. In Trentino, the population of C. melanoneura on apple was able to transmit ' $\mathrm{Ca}$. P. mali' but to a very low efficiency of $0.36 \%$ (37). Furthermore, the Trentino population of $C$. melanoneura was able to acquire the phytoplasma from infected test plants (45). Thus, genetic analyses are needed in order to confirm the postulated existence of different populations. For this, microsatellite markers for $C$. melanoneura have been developed (35) and respective studies are under way.

In conclusion, our data clearly show that neither remigrants (overwintered adults) nor specimens of the new generation (emigrants) had the capacity to acquire ' $\mathrm{Ca}$. P. mali' from apple in an efficient way. Furthermore, the phytoplasmas were not able to multiply to a titer required for successful transmission in $C$. melanoneura, probably because they cannot reach the salivary glands and multiply there. Consequently, for Germany and neighboring regions, $C$. melanoneura has to be considered to be a nonvector for the agent of AP disease. Future work should stress phytoplasma infection of different organs of $C$. melanoneura of German origin with Italian ' $C a$. P. mali' strains and vice versa as well as of $C$. picta for elucidating the reasons for the incapability of the German $C$. melanoneura in vectoring ' $\mathrm{Ca}$. P. mali'.

\section{ACKNOWLEDGMENTS}

C. J. Mayer and J. Gross thank the German Research Foundation (DFG: GR 2645/1,2) for funding; and B. Jarausch and W. Jarausch thank the Rhein-Pfalz-Wohnen GmbH (FELR), the province of Trentino, Italy (project SMAP), and the European Community (INTERREG IIIA) for funding. J. Gross is very grateful to the Stifterverband für die Deutsche Wissenschaft for additional funding (innovative research award). We thank U. Harzer, A. Fried, E. Schell, G. Henkel, M. Hellmann, W. Dahlbender, G. Hensel, W. Hein, I. Nikusch, H. Gernoth, H. Schneider, M. Trautmann, B. Strobel, D. Hagl, H. Bentz, O. Eicher, and J. Brägger for psyllid collections; E. Breitinger, A. Fuchs, J. Just, K. Lukat, and N. Schwind for technical assistance; E. Gross for language improvements; and E. Seemüller and B. Schneider for stimulating discussions.

\section{LITERATURE CITED}

1. Ahrens, U., and Seemüller, E. 1992. Detection of DNA of plant pathogenic mycoplasmalike organisms by a polymerase chain reaction that amplifies a sequence of the 16S RNA gene. Phytopathology 82:828-832. 
2. Baric, S., and Dalla Via, J. 2004. A new approach to apple proliferation detection: A highly sensitive real-time PCR assay. J. Microbiol. Methods 57:135-145.

3. Berges, R., Rott, M., and Seemüller, E. 2000. Range of phytoplasma concentrations in various plant hosts as determined by competitive polymerase chain reaction. Phytopathology 90:1145-1152.

4. Bosco, D., Palermo, S., Mason, G., Tedeschi, R., Marzachi, C., and Boccardo, G. 2002. DNA-based methods for the detection and the identification of phytoplasmas in insect vector extracts. Mol. Biotechnol. 22:9-18.

5. Boudon-Padieu, E., Larrue, J., and Caudwell, A. 1989. ELISA and dotblot detection of Flavescence dorée-MLO in individual leafhopper vectors during latency and inoculative state. Curr. Microbiol. 19:357-364.

6. Bressan, A., Clair, D., Sémétey, O., and Boudon-Padieu, E. 2006. Insect injection and artificial feeding bioassays to test the vector specificity of Flavescence dorée phytoplasma. Phytopathology 96:790-796.

7. Carraro, L., Ferrini, F., Ermacora, P., Loi, N., and Labonne, G. 2008. Infectivity of Cacopsylla picta (Syn. C. costalis), vector of 'Candidatus Phytoplasma mali' in North East Italy. Acta Hortic. 781:403-408.

8. Carraro, L., Ferrini, F., Labonne, G., Ermacora, P., and Loi, N. 2004. Seasonal infectivity of Cacopsylla pruni, vector of European stone fruit yellows phytoplasma. Ann. Appl. Biol. 144:191-195.

9. Carraro, L., Loi, N., and Ermacora, P. 2001. Transmission characteristics of the European stone fruit yellows phytoplasma and its vector Cacopsylla pruni. Eur. J. Plant Pathol. 107:695-700.

10. Carraro, L., Loi, N., Ermacora, P., Gregoris, A., and Osler, R. 1998. Transmission of pear decline by using naturally infected Cacopsylla pyri L. Acta Hortic. 472:665-668.

11. Carraro, L., Osler, R., Loi, N., Ermacora, P., and Refatti, E. 1998. Transmission of European stone fruit yellows phytoplasma by Cacopsylla pruni. J. Plant Pathol. 80:233-239.

12. Carraro, L., Osler, R., Loi, N., Ermacora, P., and Refatti, E. 2001. Fruit tree phytoplasma diseases diffused in nature by psyllids. Acta Hortic. 550:345-350.

13. Conci, C., Rapisarda, C., and Tamanini, L. 1993. Annotated catalogue of Italian Psylloideae. Atti Acc. Rov. Agiati, ser. VII, vol. II B:33-136.

14. Davies, D. L., Guise, C. M., Clark, M. F., and Adams, A. N. 1992. Parry's disease of pears is similar to pear decline and is associated with mycoplasma-like organisms transmitted by Cacopsylla pyricola. Plant Pathol. 41:195-203.

15. Deng, S., and Hiruki, C. 1991. Amplification of $16 \mathrm{~S}$ rDNA genes from culturable and non-culturable mollicutes. J. Microbiol. Methods 14:53-61.

16. Doyle, J., and Doyle, J. 1990. Isolation of plant DNA from fresh tissue. Focus (Life Technol. Inc.) 12:13-15.

17. Durnwalder, L., and Auckenthaler, A. 2006. Introduzione di nuove misure fitosanitarie per la lotta contro la malattia degli scopazzi del melo. Boll. Uffic. 49:72-74.

18. Fletcher, J., Wayadande, A., Melcher, U., and Ye, F. C. 1998. The phytopathogenic mollicute-insect vector interface: A closer look. Phytopathology 88:1351-1358.

19. Frisinghelli, C., Delaiti, L., Grando, M. S., Forti, D., and Vindimian, M. E. 2000. Cacopsylla costalis (Flor 1861), as a vector of apple proliferation in Trentino. J. Phytopathol. 148:425-431.

20. Jarausch, B., Fuchs, A., Schwind, N., Krczal, G., and Jarausch, W. 2007. Cacopsylla picta as most important Vector for 'Candidatus Phytoplasma mali' in Germany and neighbouring regions. Bull. Insectol. 60(2):189190.

21. Jarausch, B., Schwind, N., Jarausch, W., and Krczal, G. 2004. Overwintering adults and springtime generation of Cacopsylla picta (synonym C. costalis) can transmit apple proliferation phytoplasmas. Acta Hortic. 657:409-413

22. Jarausch, B., Schwind, N., Jarausch, W., Krczal, G., Dickler, E., and Seemüller, E. 2003. First report of Cacopsylla picta as a vector of apple proliferation phytoplasma in Germany. Plant Dis. 87:101.

23. Jarausch, W., Lansac, M., and Dosba, F. 1996. Long-term maintenance of nonculturable apple-proliferation phytoplasmas in their micropropagated natural host plant. Plant Pathol. 45:778-786.

24. Jarausch, W., Peccerella, T., Schwind, N., Jarausch, B., and Krczal, G. 2004. Establishment of a quantitative real-time PCR assay for the quantification of apple proliferation phytoplasmas in plants and insects. Acta Hortic. 657:415-420.

25. Jarausch, W., Saillard, C., Dosba, F., and Bové, J. M. 1995. Specific detection of mycoplasmalike organisms in European fruit trees by polymerase chain reaction. EPPO Bull. 25:219-225.

26. Jensen, D. D., Schneider, H., Griggs, W. H., and Gonzales, C. Q. 1964. Pear decline virus transmission by pear psylla. Phytopathology 54:13461351

27. Krczal, G., Krczal, H., and Kunze, L. 1989. Fieberiella florii (Stål), a vector of apple proliferation agent. Acta Hortic. 235:99-106.

28. Lauterer, P. 1999. Results of the investigations on Hemiptera in Moravia, made by the Moravian museum (Psylloidea 2). Acta Mus. Morav. Sci. Nat. 84:71-151.

29. Lee, I. M., Davis, R. E., and Gundersen-Rindal, D. E. 2000. Phytoplasma: phytopathogenic mollicutes. Annu. Rev. Microbiol. 54:221-255.

30. Lefol, C., Lherminier, J., Boudon-Padieu, E., Larrue, J., Louis, C., and Caudwell, A. 1994. Propagation of Flavescence dorée MLO (mycoplasma-like organism) in the leafhopper vector Euscelidius variegatus Kbm. J. Invertebr. Pathol. 63:285-293.

31. Lemoine J. 1991. Dépérissement du poirier: Role de Psylla pyri dans sa dissémination. Arboric. Fruit. 442:28-32.

32. Lherminier, J., Prensier, G., Boudon-Padieu, E., and Caudwell, A. 1990. Immunolabeling of grapevine Flavescence dorée MLO in salivary glands of Euscelidius variegatus-A light and electron-microscopy study. J. Histochem. Cytochem. 38:79-85.

33. Liu, H. W., Goodwin, P. H., and Kuske, C. R. 1994. Quantification of DNA from the aster yellows mycoplasmalike organism in aster leafhoppers (Macrosteles fascifrons Stål) by a competitive polymerase chain-reaction. Syst. Appl. Microbiol. 17:274-280.

34. Lorenz, K. H., Schneider, B., Ahrens, U., and Seemüller, E. 1995. Detection of the apple proliferation and pear decline phytoplasmas by PCR amplification of ribosomal and nonribosomal DNA. Phytopathology 85:771-776.

35. Malagnini, V., Pedrazzoli, F., Forno, F., Komjanc, M., and Ioriatti, C. 2007. Characterization of microsatellite loci in Cacopsylla melanoneura Förster (Homoptera: Psyllidae). Mol. Ecol. Notes 7:495-497.

36. Marzachi, C., Milne, R. G., and Bosco, D. 2004. Phytoplasma-plantvector relationship. Pages 211-241 in: Recent Research and Development in Plant Pathology. S. G. Pandalai and A. Gayathri, eds. Research Signpost, Kerala, India.

37. Mattedi, L., Forno, F., Cainelli, C., Grando, M. S., and Jarausch, W. 2008. Research on 'Candidatus Phytoplasma mali' transmission by insect vectors in Trentino. Acta Hortic. 781:369-374.

38. Mayer, C. J., and Gross, J. 2007. Different host plant odours influence migration behaviour of Cacopsylla melanoneura (Förster), an insect vector of the apple proliferation phytoplasma. IOBC/WPRS Bull. 30(4):177-184

39. Mayer, C. J., Vilcinskas, A., and Gross, J. 2008. Pathogen-induced release of plant allomone manipulates vector insect behaviour. J. Chem. Ecol. 34:1518-1522.

40. Mayer, C. J., Vilcinskas, A., and Gross, J. 2008. Phytopathogen lures its insect vector by altering host plant odor. J. Chem. Ecol. 34:1045-1049.

41. Müther, J., and Vogt, H. 2003. Sampling methods in orchard trials: A comparison between beating and inventory sampling. IOBC/WPRS Bull. 26(5):67-72.

42. Nakashima, K., and Hayashi, T. 1995. Multiplication and distribution of rice yellow dwarf phytoplasma in infected tissues of rice and green rice leafhopper Nephotettix cinticeps. Phytopathol. Soc. Jpn. 6138:451-455.

43. Ossiannilsson, F. 1992. The Psylloidea (Homoptera) of Fennoscania and Denmark. Fauna Entomologica Scandinavica (26). E. J. Brill, Leiden.

44. Palermo, S., Arzone, A., and Bosco, D. 2001. Vector-pathogen-host plant relationships of chrysanthemum yellows (CY) phytoplasma and the vector leafhoppers Macrosteles quadripunctulatus and Euscelidius variegatus. Entomol. Exp. Appl. 99:347-354.

45. Pedrazzoli, F., Gualandri, V., Forno, F., Mattedi, L., Malagnini, V., Salvadori, G., and Ioriatti, C. 2007. Acquisition capacities of the overwintering adults of the psyllid vectors of Candidatus Phytoplasma mali. Bull. Insectol. 60(2):195-196.

46. Rott, M. E., and Jelkmann, W. 2001. Characterization and detection of several filamentous viruses of cherry: adaptation of an alternative cloning method (DOP-PCR), and modification of an RNA extraction protocol. Eur. J. Plant Pathol. 107:411-420.

47. Schneider, B., Seemüller, E., Smart, C. D., and Kirkpatrick, B. C. 1995 Phylogenetic classification of plant pathogenic mycoplasma-like organism or phytoplasmas. Pages 369-380 in: Molecular and Diagnostic Procedures in Mycoplasmology. S. Razin and J. G. Tully, eds. Academic Press, San Diego, CA.

48. Seemüller, E., Kison, H., and Lorenz, K. H. 1998. On the geographic distribution and prevalence of the apple proliferation phytoplasma in lowintensity orchards in Germany. Z. Pflanzenkrankh. Pflanzenschutz J. Plant Dis. Prot. 105:404-410.

49. Seemüller, E., and Schneider, B. 2004. 'Candidatus Phytoplasma mali', 'Candidatus Phytoplasma pyri' and 'Candidatus Phytoplasma prunorum', the causal agents of apple proliferation, pear decline and European stone fruit yellows, respectively. Int. J. Syst. Evol. Microbiol. 54:12171226.

50. Smart, C. D., Schneider, B., Blomquist, C. L., Guerra, L. J., Harrison, N. A., Ahrens, U., Lorenz, K. H., Seemüller, E., and Kirkpatrick, B. C. 1996. Phytoplasma-specific PCR primers based on sequences of the $16 \mathrm{~S}-23 \mathrm{~S}$ rRNA spacer region. Appl. Environ. Microbiol. 62:2988-2993.

51. Suzuki, S., Oshima, K., Kakizawa, S., Arashida, R., Jung, H. Y., Yamaji, 
Y., Nishigawa, H., Ugaki, M., and Namba, S. 2006. Interaction between the membrane protein of a pathogen and insect microfilament complex determines insect-vector specificity. Proc. Natl. Acad. Sci. USA 103: 4252-4257.

52. Tedeschi, R., and Alma, A. 2004. Transmission of apple proliferation phytoplasma by Cacopsylla melanoneura (Homoptera: Psyllidae). J. Econ. Entomol. 97:8-13.

53. Tedeschi, R., and Alma, A. 2006. Fieberiella florii (Homoptera: Auchenorrhyncha) as a vector of 'Candidatus Phytoplasma mali'. Plant Dis. 90:284-290.

54. Tedeschi, R., Bosco, D., and Alma, A. 2002. Population dynamics of Cacopsylla melanoneura (Homoptera: Psyllidae), a vector of apple proliferation phytoplasma in Northwestern Italy. J. Econ. Entomol. 95:544551.

55. Tedeschi, R., Visentin, C., Alma, A., and Bosco, D. 2003. Epidemiology of apple proliferation (AP) in Northwestern Italy: Evaluation of the fre- quency of AP-positive psyllids in naturally infected populations of Cacopsylla melanoneura (Homoptera: Psyllidae). Ann. Appl. Biol. 142:285-290.

56. Tsai, J. H. 1979. Vector transmission of mycoplasmal agents of plant disease. Pages 266-307 in: The Mycoplasmas III. Plant and Insect Mycoplasmas. R. F. Whitcomb and J. G. Tully, eds. Academic Press, New York.

57. Vega, F. E., Davis, R. E., Dally, E. L., and Purcell, A. H. 1994. Use of a biotinylated DNA probe for detection of the aster yellows mycoplasmalike organism in Dalbulus maidis and Macrosteles fascifrons (Homoptera: Cicadellidae). Fla. Entomol. 77:330-334.

58. Wayadande, A. C., Baker, G. R., and Fletcher, J. 1997. Comparative ultrastructure of the salivary glands of two phytopathogen vectors, the beet leafhopper, Circulifer tenellus (Baker), and the corn leafhopper, Dalbulus maidis DeLong and Wolcott (Homoptera: Cicadellidae). Int. J. Insect Morphol. 26:113-120. 